\title{
Increase in Economy Rate using Modern Business Tools
}

\author{
D. Venkatrama Raju, J. Kannan
}

\begin{abstract}
E-Commerce would mention the use of electronic data transmission to implement or enhance any business process. Some people use the term internet commerce to mean electronic commerce that specifically uses the internet or the web as its date transmission medium. As important part of electronic commerce understands how firms can use it to adopt to change. The business world is changing more rapidly now than ever before.

Keywords : E.Banking, Economic Impact.
\end{abstract}

\section{INTRODUCTION}

In this new- millennium, the World order seems to have emerged from the shadows marked- More than anything else, by global trends-The 90's have been designated as the era of the computers- The ardent passion and an iron-will to comfort the society have revamped the existing scenario of the human being- Computers have become indispensable to the human life. The world has been bubbling with a new technology, about which newspapers have been writing and the people are admitting about E-Commerce.

We can hear everywhere the term E-Commerce which is a buzzword in these days. Companies all over the world is finding E-Commerce as the new platform and is all set to become the next big are of growth for the business prefers that E-Commerce is all set to become the next big area of growth in the coming ages.[1]-[4]

\section{SCOPE OF THE STUDY}

The scope of the present study mainly covers the identifications of impacting variables of the use of electronic commerce in the field of banking with customer perspectives. The impacting variables identified are systematically measure. The highlights of analytical process enabled the researcher to summaries the findings and its contribution to the users of E-Commerce services of the banking industries.

\section{OBJECTIVES:}

To review the literary background of the concept of E-Commerce in banking and the customer perspective.

To identify the impacting variables of customer satisfaction-

Revised Manuscript Received on December 30, 2019.

D. Venkatrama Raju , Professor \& Head, Department Of Science \& Humanities,Bharath Institution Of Higher Education And Research TamilNadu,India Email prof.dvraju@gmail.com

J. Kannan, Associate Professor, Department Of Science \& Humanities,Bharath Institution Of Higher Education And Research TamilNadu,India Email sjkannan1986@gmail.com

\section{LIMITATION:-}

The application of E-Commerce is restricted to the banking sector only.

The study is restricted to the customer perspective only i.e. of doesn't cover the service providers point of view.

The study excludes the technical aspects of E-Commerce.

\section{RESULTS \& DISCUSSION}

The findings of the above analytical, fourth chapter has been summarized as follows.

- The overall satisfactory level in the male segment of the customers is more or less same and found to be high if both categories are taken in to account. However, the dissatisfactory level is very significant with respect to place and distance irrespective of the gender bias the dissatisfactory level with respect to other determinants is insignificant.

- The distance and time taken for service delivery is highly dissatisfactory among different age group off respondent customers. For other determinants the satisfactory level among different age group is highly significant.

- Among different income groups except grievances and redressal of grievances, other determinants show significant dissatisfactory levels. The overall satisfactory levels among different income groups are found to be only moderate.

- Educational background of the customer play vital role in the determination of customer satisfaction. They consider problems of the customers, cost of the service and quality of the service as the key determinants for higher satisfactory level. They consider place and time as the most important element for the concern.[5]-[8]

- Irrespective of the different occupation, all the customers are highly satisfied with regard to all the factors except place and distance. In this segment the overall satisfactory level is high and the level of dissatisfaction is negligible.

- The satisfactory level at various types of account holders is high. Significant variation in dissatisfaction is identified with time, place and distance factors only. Other three factors such as grievance and its redressal, price and service show significant levels of satisfaction.

- With regard to different types of customers, except place and distance all other factors are highly satisfactory to the, among all the five factors place and distance is identified as the critical indicator that obstructs the maximization of customer satisfaction.[9]-[11] 
- Among the public and private sector banks most of the E-Commerce facilities are available with public sector banks in comparison with private sector banks. The branches of private sector banks are located only in the urban are which are hardly

- The overall satisfaction among the different basis of classification price stands the second position in the performance determination. The price factor is immaterial for most of the customers under the study.

- The grievances and grievance handling methods adopted by all the banks are excellent. There is no discrepancy in the identification of the problems of the customers and solving of such problems. That is customer is found to be the secret behind the high level of satisfaction.

- Quality of the service plays third fiddle in the ranking of the customer satisfaction. The better quality of service extended to the customers at cheaper cost i.e. the E-commerce facilities are very much cist effective.

- The time factor for the process of transaction is found to be the are of the immediate concern. Almost all the processing of E-commerce transaction. This factor causes more concern and inconvenience to the customers and the banks as well, requiring immediate attention.[12]-[16]

- The place or the distance where such electronic commerce facilities available are quite discouraging to its customers, because customers do not have close access to these facilities in their vicinity. If these facilities are extended to all the customers at all branches, the potential demand can be created.

- The overall satisfactions are found very significant in the case of grievance and handling grievances, cost of service and quality of service.

- The overall dissatisfactory level is found high in the case of place and distance and time taken for getting the facilities availed.[17]-[20]

\section{CONCLUSION}

Modern marketing is consumer oriented, involves so much of complexities to identify the needs and wants of the consumers to maximize their satisfaction. Consumer satisfaction is the mantra of successful marketing in modern times. That to it is very important vital equally in marketing services, to which banking sector is not an exception. Banking business involves several facilities, the depth of which has become unavoidable in the technological development phase the society, in the post globalize scenario. After the globalization of world trade, fierce competition is experienced world wide with regards to customer care and satisfaction. Delighted customer alo0ne will remember the service of its provider. The reason for delight of the customers may include cost of the service, quality of the service, place of its availability, time of the service and the way in which the customer's problems are identified and attended.[21]-[25]

\section{SUGGESTIONS:-}

- Place and distance of the availability of E-Commerce facilities is identified as the key factor that downsides the satisfactory level to its users. Usually banks consider several factors in to account like number of customers using E-Commerce facilities, safety, location and other operating environments to judge the financial viability. The semi urban

are and rural are do not have any E-Commerce potentialities. Therefore, such facilities to all its branches irrespective of its location. Otherwise it has to bear with the operational loss which can be justified as the socio economic objective of public sector banks. The socio- economic objectives have irrelevance of private sector banks as the primary motive is and wealth maximization.

- The processing time of the electronic commerce facilities is identified as another discouraging factor in this study. If sufficient infrastructure is available, the delay aspect it to be seriously reviewed. Otherwise the bank cannot be blame as it has been undertaken as a cost cutting measure to ensure the commercial viability. This matter requires a detailed analysis wide management for the eradication such problem.

- Both the above problem have policy implications. Careful analysis and review can alone give long lasting solutions.

\section{REFERENCES}

1. Vasanthi, S. \& Rabiyathul Basariya, S. 2019, "Influence of value analysis and cross training in industry", International Journal of Engineering and Advanced Technology, vol. 8, no. 6, pp. 1810-1811.

2. Velvizhi, R., Sri Gowtham, S. \& Jeya Priya, D. 2019, "Examination of early feedbacks for effective product retailing on E-commerce websites", International Journal of Engineering and Advanced Technology, vol. 8, no. 6 Special Issue 2, pp. 703-706.

3. Anuradha, C., Pothumani, S. \& Kavitha, R. 2019, "A novel method towards E-commerce", International Journal of Engineering and Advanced Technology, vol. 8, no. 6 Special Issue 2, pp. 535-538.

4. Thomas, J. \& Rabiyathul Basariya, S. 2019, "A study on the issues of financial ratio analysis", Indian Journal of Public Health Research and Development, vol. 10, no. 3, pp. 1079-1081.

5. Ramachandran, S. \& Rabiyathul Basariya, S. 2019, "Online marketing - study on customer satisfaction and relationship", Indian Journal of Public Health Research and Development, vol. 10, no. 3, pp. 1072-1078.

6. Priya, R., Vinothini, G. \& Cor Jesu, C.D. 2019, "The mentor-protégé relationship for professional growth", Journal of Advanced Research in Dynamical and Control Systems, vol. 11, no. 9 Special Issue, pp. 1110-1119.

7. Jannifer Rani, N., Bina Pani, S. \& Nimisha, N.S. 2019, "A study on money back polices available in LIC", Journal of Advanced Research in Dynamical and Control Systems, vol. 11, no. 9 Special Issue, pp. 833-839.

8. Saillaja, V., Jhansi Rani, K. \& Catherine, R. 2019, "Global marketing management planning and organization", Journal of Advanced Research in Dynamical and Control Systems, vol. 11, no. 9 Special Issue, pp. 489-493.

9. Saillaja, V., Jhansi Rani, K. \& Catherine, R. 2019, "The new phase of marketing information system", Journal of Advanced Research in Dynamical and Control Systems, vol. 11, no. 9 Special Issue, pp. 482-488.

10. Thoufiqulla \& Raju, D.V. 2019, "Perception of indian investor towards investment in mutual funds with special reference to mip funds", Journal of Advanced Research in Dynamical and Control Systems, vol. 11, no. 5, pp. 177-183.

11. Jasmine, K.R.M. \& Basariya, S.R. 2018, "A study on the customers benefits on mutual funds", International Journal of Civil Engineering and Technology, vol. 9, no. 4, pp. 45-48.

12. Vasanthi, S. \& Basariya, S.R. 2019, "Pros and cons of on the job training versus off the job training", International Journal of Scientific and Technology Research, vol. 8, no. 10, pp. 671-674.

13. Pavithra, J. \& Ganesan, M. 2016, "A study on awareness and impact of micro-financial schemes", International Journal of Applied Business and Economic Research, vol. 14, no. 8, pp. 5449-5460.

14. Pavithra, J., Dilli Babu, P. \& Ambuli, T.V. 2014, "A study on budgetary control at Maruti Service Masters, Chennai", International Journal of Applied Business and Economic Research, vol. 12, no. 2, pp. 151-161 
15. Gunaraja, T.M. \& Venkatrama Raju, D. 2018, "Determining factors of organisational climate with reference to leadership styles", International Journal of Mechanical Engineering and Technology, vol. 9, no. 9, pp. 1327-1332.

16. Gunaraja, T.M. \& Venkatrama Raju, D. 2018, "The role of job satisfaction and training of employees in determining organisational climate of a selected industry", International Journal of Civil Engineering and Technology, vol. 9, no. 8, pp. 1266-1269.

17. Aarathy, T.S. \& Raju, D.V. 2018, "Performance appraisal and its effects on employees with respect to it sector in Chennai city", International Journal of Civil Engineering and Technology, vol. 9, no. 6, pp. 1535-1538.

18. Aarathy, T.S. \& Raju, D.V. 2018, "Employee perception towards performance appraisal system in IT sector", International Journal of Mechanical Engineering and Technology, vol. 9, no. 5, pp. 131-135.

19. Porselvi, W., Jublee, D. \& Sivanesan, G. 2018, "A study on factors influencing adoption of technology and innovation in banking industry, tamilnadu, India", International Journal of Mechanical Engineering and Technology, vol. 9, no. 5, pp. 789-800.

20. Akessa, G.M. and Dhufera, A.G., 2015. Factors That Influences Students Academic Performance: A Case of Rift Valley University, Jimma, Ethiopia. Journal of Education and Practice, 6(22), pp.55-63.

21. Miller, G. and Shih, C.C., 1999. A faculty assessment of the academic rigor of on-and off-campus courses in agriculture. Journal of Agricultural Education, 40, pp.57-65.

22. Tsinidou, M., Gerogiannis, V. and Fitsilis, P., 2010. Evaluation of the factors that determine quality in higher education: an empirical study. Quality Assurance in education, 18(3), pp.227-244.

23. Farooq, M.S., Chaudhry, A.H., Shafiq, M. and Berhanu, G., 2011. Factors affecting students' quality of academic performance: a case of secondary school level. Journal of quality and technology management, 7(2), pp.1-14.

24. Fitsilis, P., Gerogiannis, V. and Anthopoulos, L., 2014. Ontologies for software project management: a review. Journal of Software Engineering and Applications, 7(13), p.1096.

25. Adams, J.D. and Jaffe, A.B., 1996. Bounding the effects of R\&D: an investigation using matched establishment-firm data(No. w5544). National bureau of economic research.

\section{AUTHORS PROFILE}

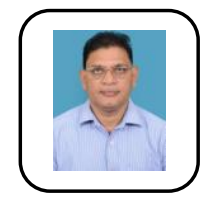

D. Venkatrama Raju , Professor \& Head, Department Of Science \& Humanities,Bharath Institution Of Higher Education And Research TamilNadu,India

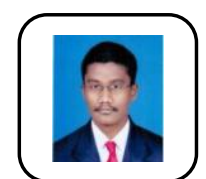

J. Kannan, Associate Professor, Department Of Science \& Humanities,Bharath Institution Of Higher Education And Research TamilNadu,India 